\begin{tabular}{|l|l|}
\hline Oficio de historiador, ¿nuevo paradigma o positivismo? & Titulo \\
\hline Barros, Carlos - Autor/a; & Autor(es) \\
\hline $\begin{array}{l}\text { De Raíz Diversa. Revista Especializada en Estudios Latinoamericanos (Vol. 1 no. 2 } \\
\text { oct-dic 2014) }\end{array}$ & En: \\
\hline México D.F. & Lugar \\
\hline $\begin{array}{l}\text { Programa de Posgrado en Estudios Latinoamericanos, Universidad Nacional } \\
\text { Autónoma de México }\end{array}$ & Editorial/Editor \\
\hline 2014 & Fecha \\
\hline Paradigmas; Positivismo; Historiador; Historiografía; Historia; América Latina; Caribe; & Temas \\
\hline Artículo & Tipo de documento \\
\hline "http//biblioteca.clacso.edu.ar/Mexico/ppel-unam/20160614033029/Barros.pdr" & URL \\
\hline $\begin{array}{l}\text { Reconocimiento-No Comercial-Sin Derivadas CC BY-NC-ND } \\
\text { http://creativecommons.org/licenses/by-nc-nd/2.0/deed.es }\end{array}$ & Licencia \\
\hline
\end{tabular}

Segui buscando en la Red de Bibliotecas Virtuales de CLACSO http://biblioteca.clacso.edu.ar

Consejo Latinoamericano de Ciencias Sociales (CLACSO)

Conselho Latino-americano de Ciências Sociais (CLACSO)

Latin American Council of Social Sciences (CLACSO)

www.clacso.edu.ar

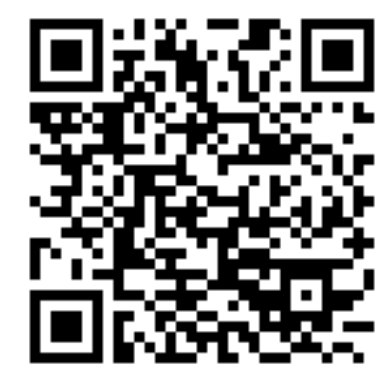




\title{
Oficio de historiador, ¿nuevo paradigma o positivismo?
}

\author{
CARlos BARros ${ }^{* *}$
}

RESUMEN. El artículo presenta un balance sobre las tendencias y los debates actuales e internacionales, desde una óptica trasatlántica y latina, considerando el método, la historiografía, la teoría y la relación de los historiadores del siglo XxI con la sociedad. Partiendo del preámbulo y las posiciones del Manifiesto de Historia a Debate (2001), y recogiendo los últimos debates de HAD en las redes sociales, analizamos la polarización historiográfica entre los partidarios de nuevos paradigmas que no hacemos tabla rasa de las vanguardias del siglo $\mathrm{xx}, \mathrm{y}$ los partidarios de un retorno al positivismo, aguijoneados por el posmodernismo radical. Repliegue historiográfico que estudiamos a través de afirmaciones, prácticas y lugares comunes, dichos y hechos, dentro y fuera de aulas y despachos. Varios datos de tipo digital y oral dan cuenta, en cuanto al regreso de Ranke, de una gran homogeneidad y transversalidad entre las diferentes especialidades, universidades y países.

Palabras Clave: Historia, Historiografía, Historiador, Positivismo, Paradigma.

Aвstract. In this paper we try to sum up new and international trends and debates, considering the transatlantic and latin viewpoints about methods, historiography, theories, and the relationship between the 21st century historians and the society. Taking as a starting point the preamble of the Manifesto of History under Debate (2001) and also the most recent debates about HAD in social networks, we will analyze the polarization of the historians between the ones who think that we need new paradigms without forgetting about the 20th century vanguards, and the ones who, in complete disagreement with the radical postmodern approaches, want the return of positivism. We will study this historiography withdrawal through the assertions, methods and clichés that are said and practiced inside and outside of the classrooms and offices. Many digital and oral data seem to demonstrate an important uniformity between the different specialties, Universities and countries, about Ranke's return.

KeYwords: History, Historiography, Historian, Positivism, Paradigm.

Recibido: 23 de abril de 2014. ACeptado: 01 de junio de 2014.

\footnotetext{
Versión escrita y completa de la conferencia de clausura del Ix Seminario Nacional de Estudos e Pesquisas "História, Sociedade e Educaçâo no Brasil", organizado por la Universidade Federal de Paraiba y la red académica histedbr. Joâo Pessoa, Paraiba, Brasil, 3 de agosto de 2012. (http://www.youtube.com/watch?v=o32iUKuv-Jc).

** Universidad de Santiago de Compostela <carlosbarros@usc.es>
} 
$\mathrm{V}$

einticuatro años después de la caída del muro de Berlín, la historia continúa aceleradamente. El mundo está inmerso en una crisis peor que la que se generó, durante la década de 1930, con el fascismo y la Segunda Guerra Mundial. No sucede lo mismo en el siglo xxi, ya que estamos en otro contexto. No pasará en cualquier caso: del siglo xx heredamos lo malo pero también lo bueno, hemos aprendido, y los actuales ciudadanos y sus movimientos sociales quieren más democracia, no menos.

Sabemos de dónde venimos históricamente pero no adónde vamos, aunque barruntamos adónde nos quieren llevar. En esta tesitura de gran calado histórico, ¿cuál es la situación de la historia que escribimos? De modo más general, ¿cuál es el futuro de la universidad y de la enseñanza pública? Parte importante de los derechos sociales y humanos que tanto sudor y sangre costó conquistar en el siglo xx son objetos de investigación para ustedes, como historiadores de la educación.

Llevamos también dos décadas de acción académica como Historia a Debate, ${ }^{1}$ en la que hemos observado e intervenido globalmente las realidades historiográficas inmediatas con congresos, listas de correos, página web, y ahora, redes sociales, desde los dos lados del Atlántico, en la que convergen historiadores de Europa latina e historiadores de América Latina. La sede física desde donde coordinamos esta vieja y a la vez joven red trasatlántica está en Santiago de Compostela, que es el principio y el final del camino de peregrinación de origen medieval más importante de Europa. ${ }^{2}$ Camino que hemos seguido historiográficamente cada Año Xacobeo donde cientos de historiadores de los cinco continentes nos encontramos en Santiago ${ }^{3}$ a fin de debatir públicamente acerca del estado de la historia y de la historia que viene. ${ }^{4}$

Compostela está en Galicia, donde se ubica la parte autónoma de España y Europa, ahí, la crisis se ha convertido en una recesión económica

${ }_{1}$ Ver: http://www.h-debate.com/Spanish/aniversarios/varios/v_a/1.htm.

2 Carlos Barros, "La peregrinación a Santiago de Compostela" (2003) en http://www.hdebate.com/cbarros/spanish/articulos/historia_medieval/peregrinacion.htm.

3 Santiago de Compostela es la capital de Galicia, "onde nasceu na Idade Media a nosa e a vosa linguas que viñeron da misma nai... galego-portuguesa”, dijimos en la versión oral de la conferencia en Joâo Pessoa.

${ }^{4}$ A modo de balance y perspectiva del I Congreso, que organizamos en 1993, titulamos a nuestra conferencia después reescrita: "La historia que viene", Historia a debate. I. Pasado $y$ futuro, Santiago, 1995, pp. 95-117 (www.h-debate.com/cbarros/spanish/historia_que\%20 viene.htm). 
que provoca que uno (o más) de cada tres miembros de la población activa estén en este momento desempleados, muchos de ellos licenciados universitarios. Una recesión gestionada por instituciones políticas que recortan gravemente nuestro Estado de Bienestar, la educación y la salud, amenazando el devenir histórico global.

Hablamos con doble conocimiento de causa, por un lado el conocimiento crítico desde una Europa meridional que sufre las peores consecuencias de la larga crisis mundial de 2008, y por el otro, el conocimiento histórico mediato e inmediato que nos viene de oficio. Tenemos mucha experiencia en Historia a Debate a la hora de interrelacionar la historia y la historiografía, los debates y los consensos, la academia y la sociedad, desde un punto de vista latino y también global. ${ }^{5}$ Un mundo latino, americano y europeo, que ha visto nacer movimientos sociales y gobiernos en el siglo XxI, que pugnan por cambiar la historia que nos tienen precocinada.

\section{POLOS HISTORIOGRÁFICOS}

El 11 de septiembre de 2001 dimos a conocer a través de la red, en Europa y América, el Manifiesto historiográfico de Historia a Debate ${ }^{6}$ que ha sido firmado hasta este momento por 584 colegas de 37 países (23 de ellos de Brasil). ${ }^{7}$ En el preámbulo de este histórico Manifiesto identificamos, a inicios del siglo XxI, cuatro grandes tendencias de la historiografía internacional: ${ }^{8}$ 1) El retorno al viejo positivismo de Ranke, Langlois y Seignobos. 2) La continuidad de las nuevas historias de los años 60 y 70. 3) La historia posmoderna. 4) Los nuevos paradigmas historiográficos, ${ }^{9}$ donde se inscriben

${ }^{5}$ Carlos Barros, "Lo latino en la historiografía global", seminario en la Université de Louvain-la-Neuve, Bruselas 15/5/2005 (http://www.goear.com/listen/11b3451/lo-latino-en-la-historiografia-global-160505-carlos-barros).

6 Manifiesto historiográfico de HaD, 11/9/2001 (www.h-debate.com/Spanish/manifiesto/ manifiesto_had.htm).

7 A diferencia de México y Argentina, la participación de la historiografía brasileña en Historia a Debate viene siendo inferior a su importancia objetiva, resultado probable de un insuficiente intercambio histórico-cultural entre Brasil y el resto del universo latino (americano y europeo) que hemos de superar en beneficio mutuo.

${ }^{8}$ Hemos desarrollado este planteamiento en "Panorama actual de la historiografía internacional”, Universidad del Atlántico, Barranquilla, 2009 (http://www.youtube.com/ user/HistoriaDebate?feature=mhum\#p/c/E9C70E13BB2D249D/0/GlvoeMQUBMQ).

9 Decimos "nuevos paradigmas" en lugar de "nuevas historias" para que no haya confusión con las vanguardias pasadas y significar así los cambios en la matriz disciplinar que se proponen con el objeto de rebasar, historiográficamente hablando, tanto las limitaciones 
en lugar destacado los logros de Historia a Debate. Doce años después del Manifiesto de 2001 constatamos una neta polarización del debate y del consenso, ya sean implícitos o explícitos, en el seno de la historiografía internacional, entre las dos posiciones o tendencias actuales, más o menos organizadas o latentes.

Detectamos un acusado retraimiento de bastantes colegas hacia las certezas positivistas como si éstas, de raíz alemana del siglo XIX, fuesen las "últimas fortalezas" donde ha de refugiarse nuestra disciplina, después de la caída del marxismo y Annales. Todo hay que decirlo, por una epistemología posmoderna que equipara -en su versión más radical, filosófica-, historia con ficción, que pretende que retrocedamos más atrás que Ranke, a la etapa pre-paradigmática de nuestra disciplina, en el lenguaje histórico-científico de Thomas S. Kuhn.

Paralelamente a esta marcha atrás ${ }^{10}$ estamos inmersos en un movimiento hacia un nuevo paradigma, entendido como nuevo consenso, del que Historia a Debate forma parte de manera consciente y global como sector organizado de una academia historiográfica internacional que busca y encuentra de varias formas; una síntesis coherente y articulada, con la mirada hacia adelante, entre la historiografía rompedora del siglo xx y la nueva historiografía que nace con este nuevo siglo, dentro y fuera de Internet. Pensamos y modelamos el presente y futuro historiográfico alrededor de dos ejes: a) Asunción y reformulación autocrítica de las aportaciones esenciales de las vanguardias historiográficas del pasado siglo. b) Nuevas preguntas y nuevas respuestas, tanto teóricas como aplicadas, para la historia que estamos escribiendo en este siglo, y no me refiero solamente al paradigma digital, el reto más evidente. ${ }^{11}$

En el tránsito del siglo $\mathrm{xx}$ al siglo xxI sufrimos un doble proceso crítico, que aún sigue sin cerrar, la crisis de la historia y la crisis de la

del siglo xx como el retorno de algunos al siglo xix, así como procurar la adaptación al siglo xxI; este nuevo paradigma implica para Historia a Debate la redefinición de la historia como ciencia.

${ }^{10}$ Inestable, pragmática y escasamente reflexionada: condenada en último extremo al fracaso ante la imposibilidad de regresar al contexto histórico del siglo xix que hizo posible y necesario al positivismo historiográfico original, la primera revolución científica de nuestra disciplina.

${ }^{11}$ Carlos Barros, "La nouvelle historiographie digital", Katholieke Universiteit Leuven, Bélgica, 8 de marzo de 2013 (http://www.youtube.com/watch?v=Ii-ugaGITug). 
historiografía, ambas relacionadas estrechamente; ${ }^{12}$ se explican mutuamente y encontrarán su salida juntas si somos inteligentes y sabemos leer historiográficamente la historia más inmediata y sus efectos, deseados e indeseados, sobre la historia académica.

En la segunda década de este nuevo milenio, la universidad y la investigación están en el ojo del huracán, son presas fáciles de las políticas neoliberales. Los que laboramos, enseñamos e investigamos encuadrados en ciencias humanas y sociales que no se rigen por la "lógica" del mercado, que prefiere más una historia erudita, academicista y por lo tanto marginal que una historia renovadora, crítica y social. ${ }^{13}$ Con todo, el relativo pero llamativo auge del positivismo clásico ${ }^{14}$ también se explica, especialmente entre las nuevas generaciones, por un "nuevo pesimismo" sobre el presente y el futuro de la Historia como disciplina científica y crítica, que no tiene sólo como portadores a los historiadores tradicionales de toda la vida, sino también a historiadores progresistas decepcionados ${ }^{15}$ de la escuela de Annales, el materialismo histórico y el neopositivismo cuantitativista e hipotético-deductivo de los años $70 .{ }^{16}$ Desencanto, que estos profesores

${ }^{12}$ Sería extraño, antihistórico, que atravesando la historia que vivimos en un momento de crisis, su escritura permaneciera igual, de hecho la polarización historiográfica que estamos analizando tiene un devenir endógeno y otro exógeno interrelacionados.

${ }_{13}$ Sin considerar creciente y desmedida influencia, del poder financiero y económico global sobre la sociedad y la cultura, a partir de 1989, la crisis no se entiende irreversible con las nuevas historias académicas a finales del siglo xx.

${ }^{14}$ Optó por no identificar terminológicamente como neopositivista al retorno actual a la historia tradicional porque es, más bien, un regreso al objetivismo decimonónico de pretender una historia "tal como fue" (Ranke); tampoco queremos confundir el positivismo como refugio actual para excombatientes (en sentido febvriano) con la epistemología neopositivista popperiana que concedía cierto margen al investigador sobre las fuentes o con la historia cuantitativista o serial, nueva historia que participó a través de la historia económica en la revolución historiográfica del siglo xx, junto a Annales y el marxismo; Carlos Barros, "El paradigma común de los historiadores del siglo xx", Medievalismo, Madrid, núm. 7, 1997, pp. 235-262 (www.h-debate.com/cbarros/spanish/paradigma_comun. htm).

${ }^{15}$ En la encuesta internacional sobre el "estado de la historia" que organizamos entre 1999 y 2001 nos encontramos con que la mayoría de los historiadores entrevistados valoraban en positivo las tendencias Annales y el marxismo en términos de pasado, pero no de presente y menos de futuro, Carlos Barros, "El estado de la historia. Encuesta internacional", Vasconia. Cuadernos de Historia y Geografía, Eusko Ikaskuntza-Sociedad de Estudios Vascos, San Sebastián-Donostia, núm. 34, 2005, pp. 9-21 (www.h-debate.com/ cbarros/spanish/articulos/nuevo_paradigma/estado.htm).

${ }^{16}$ Esta desilusión historiográfica de una buena parte de la generación influida por el movimiento del 68 también fue política y finalmente biológica, si bien nadie tiene 
transmiten voluntaria o involuntariamente a unos alumnos que captan de sus enseñanzas que lo único "sólido" desde el punto de vista de la escritura de la historia es aquello de que la "historia se hace con documentos" y punto: ${ }^{17}$ aserto que tanto y tan justamente criticaron Marc Bloch y Lucien Febvre en la primera mitad del siglo xx. ${ }^{18} \mathrm{Ni}$ se les ocurre pensar a estos alumnos, con independencia de su nivel de compromiso social o ideología política, que es posible y necesaria una renovación historiográfica del siglo Xxi bajo la inspiración de los movimientos sociales indignados, ${ }^{19}$ del mismo modo que en el siglo $\mathrm{xx}$ las vanguardias historiográficas se inspiraron en el movimiento obrero, estudiantil, feminista y ecologista.

En el II Congreso de Historia a Debate (1999) hablé ya (hoy se puede decir que precozmente) sobre el "retorno de la historia", ${ }^{20}$ revelando que había una doble vuelta a la historia: por un lado, hay mayor interés de la sociedad, la cultura (empezando por los escritores de ficción) y la políti$\mathrm{ca}^{21}$ por la historia, que continúa en el presente; por el otro, un regreso, que se fue haciendo más evidente con los años, a los temas tradicionales (biografías de "grandes hombres", historia acontecimental, militar, institucional, etc.) y, lo que es peor, a las metodologías objetivistas del viejo positivismo que el marxismo y Annales creyeron haber derrocado en las décadas centrales del pasado siglo. ${ }^{22}$

derecho a negarles su aporte renovador al oficio de historiador; Carlos Barros, "Historia a Debate: balance historiográfico" (México, 2010) en http://www.youtube.com/user/ HistoriaDebate?feature $=$ mhum\#p/c/A451FC6D7534C343/12/p60frWr4SIY.

${ }^{17}$ Ch. V. Langlois, Ch. Seignobos, Introduction aux études historiques, Paris, 1898, p. 13 (http://classiques.uqac.ca/classiques/langlois_charles_victor/intro_etudes_historiques/ seignobos_etudhisto.pdf).

${ }^{18}$ Justo es reconocer que los fundadores del marxismo criticaron la historia tradicional antes que Annales, en el marco de una nueva filosofía para comprender y cambiar el mundo (o sea, la historia), aunque lo distintivo de los annalistes fue transformar la manera de hacer la historia (influidos por el marxismo y los movimientos sociales) en un registro más académico-historiográfico que social y político.

19 Carlos Barros, "Historia Inmediata: de Chiapas a los indignados", Sinaloa, 2011 (http:// www.youtube.com/watch?v=bHqkczWoBwE).

20 "El retorno de la historia", Historia a debate. I. Cambio de siglo, Santiago, 2000, pp. 153-173 (http://www.h-debate.com/cbarros/spanish/articulos/nuevo_paradigma/retornohistoria.htm).

${ }^{21}$ Los políticos promueven generalmente el regreso de la historia tradicional, políticainstitucional, en razón de su oficio y también como medio de defender o promover las naciones y los Estados en tiempos de globalización.

${ }^{22}$ Temáticamente así fue pero no en lo puramente epistemológico que permaneció latente. 


\section{UN PASO ATRÁS}

A partir de la experiencia de Historia a Debate como plataforma internacional para el examen de la evolución de nuestra disciplina, ${ }^{23}$ constatamos que en esta segunda década hay un claro repliegue de bastantes colegas, ${ }^{24}$ incluidos protagonistas de la revolución historiográfica del siglo $\mathrm{xx},{ }^{25}$ acogidos ahora a la certeza final de la historia "tal como fue". Noción objetivista "total" que resulta bien ajena a lo que se entiende hoy en día por método científico, es lo que en los años 70 solíamos tildar (peyorativamente) de "cientificismo". ${ }^{26}$ Hablamos de un positivismo científicamente retrasado que restringe y limita la investigación a una empiria elemental: uso de fuentes como único criterio para definir una actividad como científica. Hiperobjetivismo que contradice la no menos demostrable, empíricamente, ${ }^{27}$ intrusión del sujeto cognoscente en la investigación, generalmente para bien; desde la selección del tema a las conclusiones, pasando por las hipótesis y demás fases del proceso de la investigación, cuya verdad resultante viene a ser consecuencia de la paciente y creativa ( $\mathrm{re}$ ) construcción del objeto por parte del investigador. ${ }^{28}$

El revival historiográfico iniciado en los años 90 que suele pasar desapercibido para el historiador pragmático, urge sacarlo a la luz y combatirlo

${ }^{23}$ Carlos Barros, "Historia a Debate, desde los congresos a las redes sociales" (Diamantina, 2012) en http://www.youtube.com/watch?v=kl6TsMmCwaU.

${ }^{24}$ En realidad el repliegue es intergeneracional, destacamos la "conversión" de una parte de la generación de los años 60 y 70 por su significado e influencia, pero el retroceso se da igual entre profesores más jóvenes que no llegaron a protagonizar cambio alguno, y, como resultado final, entre estudiantes e investigadores en formación, que reciben así escasa ayuda para sintonizar la historia que deben aprender en clase con el tiempo que les toca vivir.

${ }^{25}$ Uno de los muchos síntomas de esta parcial vuelta atrás de la historiografía en el siglo xxi es la forzada "desaparición" de la revolución historiográfica de Annales y el marxismo: para los retornados la "única" revolución científica de la historia como disciplina del positivismo decimonónico.

26 "Cientismo" en algunos países americanos por influencia del inglés.

${ }^{27}$ Jerzy Toposlky demostró meridianamente hace medio siglo que la gran mayoría de las operaciones que realiza el historiador cuando investiga dependen del "conocimiento no basado en fuentes", Metodología de la historia, Madrid, 1982 (ed. original en polaco, Varsovia, 1973), pp. 309-329.

${ }^{28}$ Carlos Barros, "Por un nuevo concepto de la historia como ciencia" (2005) en http:// www.h-debate.com/Spanish/presentaciones/lugares/quito.htm. 
con argumentos. ${ }^{29}$ Es una involución que suele pasar inadvertida justamente porque el positivismo genuino se caracteriza por desvalorizar la historiografía, el debate y la reflexión de los historiadores; es la táctica perfecta para cambiar (los temas a estudiar, por ejemplo) sin que nada cambie (el concepto básico de Historia). El positivismo es una suerte de paradigma o consenso pasivo, usualmente no organizado ${ }^{30}$ pero real y efectivo, aunque potencialmente reversible toda vez que empuja "hacia atrás" cuando la historia se mueve como nunca "hacia adelante". Lo que es seguro es que las primaveras que la historia como oficio, y más aún como presencia inmediata, requiere en este nuevo siglo que sea comprensible ${ }^{31}$ y no con ese rocambolesco y pernicioso giro ultraconservador de los orígenes de la Historia como disciplina profesional.

El mundo actual exige de la ciencia mucho más que un positivismo simplista. Para responder a esta demanda se precisa una metodología científica más compleja y actual, esto es, más global. Si bien una evolución paradójica estimula la fragmentación y la ultraespecialización de las disciplinas académicas, éste beneficia en primera instancia el reduccionismo decimonónico de la historia al uso de fuentes para la recopilación de datos y fechas, nombres y lugares, con el aplauso insonorizado de un posmodernismo que en su afán trivializador ${ }^{32}$ teoriza como "excelente" el paradigma de la segmentación y la relatividad absoluta —idealista- del saber histórico.

Algunos preguntarán si esta retirada, tan desordenada como decidida, de un sector de la historia académica a los cuarteles de invierno es defini-

${ }^{29}$ Este giro positivista es ahora más peligroso para el presente y futuro de la historia que el paradigma posmoderno, asimismo hipercrítico con las vanguardias del siglo xx: de reducida influencia entre los historiadores de profesión si bien genera efectos positivos como interés por la teoría y la historiografía de la historia o las autobiografías de historiadores.

${ }^{30}$ La primigenia posición hegemónica del positivismo entre los historiadores de profesión explica que actúe como paradigma oculto, siendo invariablemente sus críticos quienes han de organizarse para hacer avanzar la disciplina.

${ }^{31}$ El positivismo ha ido recuperando parte del espacio vacío dejado por la caída de las pasadas vanguardias como forma de rechazo hacia nuevos paradigmas hoy en construcción, sin debate explícito.

${ }^{32} \mathrm{El}$ posmodernismo en historia también tuvo consecuencias positivas como revalorizar los discursos de los sujetos históricos o las autobiografías de historiadores (egohistoria), coadyuvando además al auge del interés por la historiografía y la teoría de la historia entre los historiadores de oficio (no positivistas), que tiene su máxima expresión en el mundo académico latino en la trayectoria ascendente de la red / comunidad de Historia a Debate. 
tiva, si tiene futuro. Esperemos que no, estaría presagiando la decadencia de la Historia como ciencia social en la sociedad de la información. Como dijo un célebre filósofo político ruso de principios del siglo $\mathrm{xx}^{33}$ en ocasiones conviene dar un paso atrás para avanzar dos pasos adelante. Pueda que, finalmente, no haya mal que por bien no venga. Estamos luchando porque así sea, de forma que aclaradas las consecuencias negativas del retorno a la Historia según Ranke, el debate se salde con un reforzamiento epistemológico y metodológico de los avances historiográficos. Previa toma de conciencia de que no estamos en el siglo XIX, ni siquiera en el fabuloso siglo $\mathrm{xx}$, sino en un nuevo siglo global y complejo, sujeto a un intenso cambio histórico que también está impulsando una escritura diferente de la historia, pensada hacia adelante, empeñada en derivar hacia los márgenes a los empecinados en mirar hacia atrás como la mujer de Lot.

\section{PRUEBAS INDICIARIAS}

Si no queremos que los sectores retardatarios, internos y externos, que venimos criticando arrastren al conjunto de nuestra disciplina con la inercia y pasividad de muchos, es necesario generar conciencia sobre el silencioso retroceso que se está dando en la historia que se hace en la academia de forma "inconsciente": en los dos sentidos del término, ignorancia e irresponsabilidad.

Para convencer a dudosos e informar a quienes están alejados de este tipo de reflexiones, vamos a detallar y examinar una serie de palabras y frases, argumentos y hábitos que se vienen transmitiendo y repitiendo acríticamente en despachos y pasillos, en conversaciones informales entre colegas y también en las aulas, ante los alumnos, incluso por escrito. Identifiquen los signos indiciarios, el fenómeno es universal. ${ }^{34}$ Síntomas y pruebas de cierto repliegue historiográfico en el siglo xxi son, en realidad, señales de alarma para una disciplina donde muchos de sus componentes semejan no saber, o no querer saber, a dónde vamos y a dónde nos quieren

\footnotetext{
33 Vladimir Ilich Ulianov, Lenin (1870 - 1924), autor de una sesuda obra filosófica antipositivista (Materialismo y empirocriticismo, 1908) y actor destacado de la Revolución rusa de 1917.

${ }^{34}$ El ámbito del retorno al positivismo tradicional es internacional, se da en todos los continentes e historiografías nacionales, favorece el auge del nacionalismo y su historia factual, a contrapelo de la globalización, si bien resulta más notorio allá donde la influencia del marxismo y Annales fue mayor en los años 60 y 70.
} 
llevar. "Neutrales" en apariencia, como dicta el positivismo, representan sectores que miran provocativamente hacia atrás, "saltándose" el siglo $\mathrm{xx},{ }^{35}$ para imponer sus propios intereses, ${ }^{36}$ en contraposición con sectores críticos, menos o nada vinculados al poder académico, mediático, económico y político, que miran con vocación profesional y provecho social un presente y un futuro alternativos. ${ }^{37}$

Empecemos por analizar el significado de ser buen historiador ${ }^{38}$ o hacer buena historia. Es sencillo, trabajar con fuentes. ${ }^{39} \mathrm{La}$ "historia se hace con documentos" (Langlois y Seignobos), lo demás es secundario, aun perjudicial, piensan muchos. ${ }^{40}$ Un rebrote, luego, de la "idolatría de las fuentes" que denunció hace setenta años Marc Bloch en Métier d'historien (publicado en español como Introducción a la Historia en 1952), caído por desgracia en los últimos años en el olvido. ${ }^{41}$ Yo sigo aconsejando a mis

${ }^{35}$ El retorno que denunciamos de una parte de la historia académica al positivismo alemán del siglo XIX, tiene lugar a partir de 1989 de forma simultánea al auge del fundamentalismo del libre mercado (neoliberalismo, identificado entonces con el neoconservadurismo) y las proclamaciones (desmentidas por los hechos) del fin de la historia y de la modernidad; movimientos académicos, culturales y políticos tendencialmente convergentes que suponen un lucrativo regreso a los principios de la economía clásica por medio del Estado, de una parte, y a la historia (posmoderna) entendida como parte de la literatura, de la otra, ambas anteriores a Marx.

${ }^{36}$ No es el caso de los jóvenes académicos que miran paradójicamente hacia atrás, al margen de su tiempo, perjudicando sus intereses de futuro.

${ }^{37}$ Una vez desparecidos del horizonte los fines preestablecidos de la historia, todo depende contextualmente de la correlación de fuerzas entre los sujetos históricos, hoy paradójicamente más ideologizados entre las clases dominantes (neoliberales) que entre las clases subalternas, en cuyas acciones el marxismo no juega un papel hegemónico.

38 También se oía decir, en los años 90, que "no hay una crisis de la historia sino de los historiadores", entendiendo la historia como una categoría abstracta "anterior" a los historiadores, sugiriendo en consecuencia que hay "buenos" y "malos" historiadores según cuánto y cómo estuviesen documentados sus trabajos, obviando la importancia decisiva de la metodología aplicada, el enfoque historiográfico y la formación teórica en la calidad del resultado de una investigación.

${ }^{39}$ Esta definición fue revolucionaria a fines del siglo xix: más de una centuria después se reduce a una condición necesaria pero harto insuficiente para definir una buena historia.

${ }^{40}$ Formulación reciente de "la historia se hace con documentos" es reprobar el uso público de la historia por parte de los sujetos políticos, y otros agentes externos, reclamando para los historiadores el monopolio de la verdad histórica (por su pericia en el manejo de fuentes), v. g. Julián Casanova, "Los usos y abusos de la historia”, en El País, 12/12/2013, (http://politica.elpais.com/politica/2013/12/11/actualidad/1386794209_835358.html.

${ }^{41}$ Un alumno me explicaba, no hace mucho, cómo inclusive los profesores que hacen referencia en clase a las aportaciones de Annales, el marxismo y el neopositivismo, eluden 
alumnos que para aprender el oficio lean tres breves obras fundamentales del siglo xx, la citada Introducción a la historia (1941-1943) ${ }^{42}$ de Marc Bloch; Combates por la historia (1952, francés; 1970, español) de su compañero Lucien Febvre y ¿Qué es la historia? (1961, inglés; 1983, español) del marxista E. H. Carr. Pertenecen, ciertamente, a otro tiempo histórico e historiográfico, pero recobran actualidad cuando unos adversarios que parecían derrotados, nos quieren hacer retroceder ahora a su vetusta manera de hacer la historia. Las críticas al positivismo del siglo xix por parte de los fundadores de Annales y del marxismo historiográfico de Past and Present, están tanto o más vigentes en el siglo xxi que en la primera mitad del siglo $\mathrm{xx}$, por mucho que debamos autocríticamente asumir todo lo que fracasó de las nuevas historias, ${ }^{43}$ adaptando en general el métier al contexto histórico de la era global.

Con lo anterior vuelve el mito positivista de la neutralidad o imparcialidad del historiador, signo asimismo de una supuesta buena historia. ${ }^{44}$ Eco anacrónico de la ya citada y harto divulgada frase de Leopold von Ranke: "la historia es conocer el pasado 'tal como fue', como si tal cosa fuese posible.... Concepto absoluto de la verdad histórica más propio, según ya dijimos, de una religión cientifista ${ }^{45}$ que de una historia científica. La propia práctica historiográfica, individual y colectiva, demuestra cotidianamente que la verdad empírica que descubrimos es inseparable del propio historiador, de sus competencias y sus valores. ${ }^{46} \mathrm{Mal}$ asunto que

mencionar la crítica del positivismo tradicional que llevaron a cabo estas tendencias historiográficas renovadoras del siglo xx.

${ }^{42}$ Esta obra metodológica inacabada de Marc Bloch, fue redactada en condiciones de clandestinidad durante los tres años anteriores a su detención y fusilamiento por los nazis en 1944, Apologie pour l'histoire ou Métier d'historien (edición crítica de Étienne Bloch), París, 1993, p. 39.

${ }^{43}$ Ciertamente el retorno de Ranke, Seignobos y Langlois se debe asimismo a los defectos, limitaciones y errores cometidos por los nuevos historiadores, y no solamente al cambio histórico de contexto económico y social, político y de mentalidad.

${ }^{44}$ Variante muy difundida por los pasillos y aulas de las facultades es afirmar que el historiador no es un "juez", ni tiene la obligación de decir lo que está "bien" o "mal" en la historia, en resumen que la historia y la ética no deben "mezclarse": argumento ruin utilizado por determinados sectores de la Real Academia de la Historia en España para “justificar" el golpe militar de 1936 y el franquismo, reemplazando la deontología de nuestro oficio por un "todo vale" reaccionario.

${ }^{45}$ Cientista se usa en algunos países latinoamericanos por influencia del inglés.

${ }^{46}$ En el punto I del "Manifiesto historiográfico" de HaD redefinimos la historia como una "Ciencia con sujeto. Ni la historia objetivista de Ranke, ni la historia subjetivista de 
determinados historiadores no sepan (los más jóvenes) o no quieran (los más desencantados) distinguir el mito de la realidad en las propias definiciones de nuestra disciplina, alimentando un imaginario hiperobjetivista que nos hace perder credibilidad conforme nuestro público se amplia y deviene, gracias a la sociedad de la información y el conocimiento, más culto, más crítico y más exigente. ${ }^{47}$

Retroceso epistemológico que ignora, o lo que es peor, desconoce, un siglo de cambios en el concepto de ciencia que poco tiene ya que ver con el empirismo decimonónico o con el racionalismo del siglo xVII, construidos por creyentes en la perfección divina de la realidad física como Descartes o Newton. O el repliegue historiográfico que nada sabe, o nada quiere saber, de los descubrimientos de la ciencia ${ }^{48}$ desde inicios del siglo xx: considerando en su ignorancia, un siglo después de Heisenberg y Einstein, que la relatividad (literalmente, condicionamiento por el sujeto) de la ciencia de hoy es un invento... posmoderno.

Hemos observado igualmente cómo se impone en medios académicos de distinto signo ideológico la eliminación del término "futuro" del lenguaje historiográfico. ${ }^{49} \mathrm{El}$ futuro no interesa al historiador, vienen a decir recuperando la vieja idea reaccionaria de que los historiadores no somos profetas ni adivinamos el porvenir, como si se tratara de eso... En plena marcha atrás historiográfica muchos han dejado caer imprudentemente el "futuro" del trinomio pasado-presente-futuro (estudiar el pasado para comprender críticamente el presente y construir un futuro mejor), ${ }^{50}$ que tanto y tan bien nos sirvió a lo largo del siglo xx para ubicar nuestro oficio en el continuum temporal. El desinterés por relacionar el pasado con el

la posmodernidad: una ciencia con sujeto humano que descubre el pasado conforme lo construye" (www.h-debate.com/Spanish/manifiesto/manifiesto_had.htm).

${ }^{47}$ Objetivismo epistemológico que sirve para retroalimentar el círculo vicioso y academicista de colegas que escriben para otros colegas, abandonando un público cada vez más volcado hacia las novelas históricas, algunos de cuyos autores presentan incluso como más reales que la historia hecha desde la universidad.

${ }^{48}$ Y menos todavía quieren saber de la historia de la ciencia, disciplina emergente impulsada en la segunda mitad del siglo xx por Popper, Kuhn y Lakatos.

${ }_{49} \mathrm{Al}$ mismo tiempo que gana terreno en ciencias sociales un saber, con vocación interdisciplinar, llamado "prospectiva" que tiene por finalidad generar científicamente modelos de futuros posibles y mantenerlos actualizados, usando para ello datos históricos.

${ }^{50}$ Futuro socialista se decía por parte de la historiografía marxista (significada en España por Josep Fontana y su obra Historia. Análisis del pasado y proyecto social, Barcelona, 1982), que dejó de nombrarse desde la caída del socialismo llamado real, sin que las experiencias y reivindicaciones en América del "socialismo del siglo xxı" lo hayan resucitado demasiado. 
presente y más aún con el futuro es claro síntoma, causa y consecuencia del retorno sigiloso (parcial o total) de no pocos historiadores ex-marxistas y exannalistes al antaño denostado positivismo. ${ }^{51}$ Si observan, raramente se habla de historia y futuro, ${ }^{52}$ en el mejor de los casos se relaciona pasado y presente. Pensemos, ¿qué utilidad social tiene una historia que dice comprometerse críticamente con un presente pero "interrumpe" su análisis cuando se trata de interactuar con los actuales actores históricos a fin de proyectar su conocimiento coadyuvando a la viabilidad de futuros alternativos?

Otro indicio nefasto del revival positivista es separar y enfrentar la historia (académica) con la memoria (social), el objeto con el sujeto histórico. El enfoque historia versus memoria formulado en Francia por Pierre Nora, ${ }^{53}$ con bastante oposición en España y países latinoamericanos, ${ }^{54}$ entraña una insensibilidad suprema hacia los vencidos de la historia oficial y enfrenta torpemente la historia profesional con los sujetos históricos, sociales y políticos, tanto pasados como actuales. Una consecuencia más de la típica cosificación que el positivismo historiográfico transmite a sus objetos, en este caso seres humanos que sufrieron las consecuencias de las guerras y las dictaduras del siglo $\mathrm{xx}$, cuyas familias, descendientes $\mathrm{y}$ compañeros organizan movimientos por la memoria y los derechos humanos, con la cada vez más frecuente colaboración de historiadores y otros académicos. Víctimas de la historia que siguen mereciendo, en España y otros lugares, menos consideración por parte de los poderes públicos y colegas de tendencia conservadora que los monumentos, los sitios y las fechas de los "grandes acontecimientos" de las historias oficiales. ${ }^{55}$

\footnotetext{
${ }^{51}$ Aderezado ahora con temas y elementos posteriores como guindas de un pastel conceptual e inequívocamente positivista.

${ }^{52}$ Puede tener su lógica personal a partir de cierta edad, pero hace daño a la historia como disciplina, hoy en peligro por el precoz conservadurismo de no pocos jóvenes que retroalimenta el desaliento cívico e historiográfico de parte de sus profesores.

${ }^{53}$ Carlos Barros, "Historia, memoria y libertad" (Santiago de Compostela, 2012) en http:// www.h-debate.com/cbarros/spanish/articulos/memoria/cb.htm).

${ }^{54}$ En el siglo xx nos llegaba de Francia el marxismo y la escuela de Annales, ahora, con menos influencia, por supuesto, los retornos de una historia tradicional cuyos representantes detentan la iniciativa historiográfica en el país galo.

${ }^{55}$ Los lieux de mémoire de Pierre Nora, justamente, cuyo conocimiento es siempre históricamente útil, pero no tanto como el contenido humano y social de la memoria histórica.
} 
Nos alarma asimismo que haya historiadores que descalifiquen como de "relativismo" todo lo que no sea objetivismo total: la intención no es otra que justificar un tardío entusiasmo por el primitivo concepto científico de la historia, con el peregrino pretexto de "combatir" al posmodernismo. ${ }^{56}$ Ignorando consciente o inconscientemente el diccionario, donde dice que "relativo" es, en su primera acepción, lo "que guarda relación con”. Olvidando que la verdad histórica es fruto de la relación continuada del historiador con sus fuentes, como defendió (sin demasiado éxito) E. H. Carr en los años 60 y $70 .{ }^{57}$ Desdeñando, en suma, la práctica del oficio que nos enseña que las fuentes no hablan solas: responden a las preguntas, hipótesis y problemas, dependiendo según qué, quién y cómo se planteen. Otra muestra más de que, normalmente, no se reflexiona sobre el trabajo que se hace.

Otro argumento probador del retorno al positivismo ${ }^{58}$ es considerar cosa de filósofos y otros científicos sociales ${ }^{59}$ la tarea de reflexionar sobre la historia, ${ }^{60}$ "pensar la historia", decía Pierre Vilar, es todo lo contrario. El buen historiador tendría que leer filosofía, psicología, economía, sociología, antropología, filología, politicología..., en función de sus temas y enfoques de interés, si quiere hacer en verdad una buena investigación. Se trata pues del reverso y el anverso de una misma moneda: los colegas que piensan que la reflexión, abstracción más allá de las fuentes, no es tarea de historiadores, suelen concentrarse en trabajos únicamente empíricos,

\footnotetext{
${ }^{56}$ En realidad, los extremos se tocan y se reparten los papeles tácitamente: el positivismo de los retornados coincide con la epistemología posmoderna del giro lingüístico-narrativista en que ambos hacen "desaparecer" de un plumazo las vanguardias historiográficas del siglo $\mathrm{xx}$ y sus relativas pretensiones de conceder al investigador un papel activo, más allá de las fuentes, en el proceso de conocimiento histórico.

57 Carlos Barros, "Por un nuevo concepto de la historia como ciencia" (2005) en http:// www.h-debate.com/Spanish/presentaciones/lugares/quito.htm.

${ }^{58}$ Relacionado también con el truco barato de atribuir al posmodernismo todo reconocimiento del condicionamiento del objeto de investigación por el sujeto cognoscente, algo de sentido común.

59 Me consta que tamaña necedad ha sido proferida en algunos tribunales académicos y también ante los alumnos, dando a entender que investigar la historia es más un trabajo técnico que intelectual.

${ }^{60}$ En Historia a Debate entendemos por "historia pensada" la reflexión (vinculada a la experiencia empírica) sobre metodología, historiografía, teoría de la historia, relación historia-sociedad, didáctica de la historia e historia inmediata.
} 
pragmáticos, "concretos", 61 siempre provechosos pero jamás excelentes, por falta precisamente de conocimiento y reflexión sobre el método, la historiografía y la teoría.

El seguimiento que vuelven a encontrar hoy estas prédicas en favor del no-pensar-la-historia ${ }^{62}$ revela el riesgo de declive que corre nuestra disciplina, respecto del pasado siglo cuando gracias a los movimientos de cambio, historiográfico y social, la historia entró a formar parte de manera relevante del sistema universitario público y de las ciencias sociales. ${ }^{63}$ Consecuencia de esta deriva es la añeja tentativa, que cobra fuerza con el regreso a Ranke, de subordinar la historia a otras disciplinas más sabias y pensadoras, sociología, filosofía, antropología, economía, ciencia política, etc., que se aprovechan de nuestros resultados empíricos para implementar sus análisis reflexivos y aportar una perspectiva temporal - casi siempre imprescindible - a sus investigaciones sobre lo inmediato. Inaceptable división del trabajo que aspira a reproducir la historia (lo consigue a menudo) como una "ciencia auxiliar" de la filosofía y las ciencias sociales, ${ }^{64}$ disciplinas que están por otro lado tanto o más en crisis que la propia historia.

Más rasgos de la involución conservadora de la historiografía internacional. Aleccionar y poner en práctica la idea de que la ambición intelectual es mala para el historiador, sobre todo si es joven, ${ }^{65}$ en consonancia

${ }^{61}$ El término concreto se utiliza en ocasiones como "definición" del trabajo "propio" del historiador, en su versión más positivista, en oposición a la historia pensada que han preconizando las nuevas historias del siglo xx: lo practicaron bien poco ya que sólo puntualmente sus grandes representantes publicaron algunas reflexiones, tipo de actividad que Historia a Debate democratizó y dio continuidad a partir de 1993.

${ }_{62}$ A la vez que crece la inquietud de otros historiadores por vincular la historia pensada con la historia empírica.

${ }^{63}$ En la Francia de Annales la historia llegó a vertebrar las ciencias sociales (como se puede ver todavía hoy en la estructura de la eHess), lo que agravó una crisis finisecular de la que estamos saliendo en el universo académico latino como Historia a Debate.

${ }^{64}$ El mismo Jürgen Habermas ha defendido esta peculiar división del trabajo entre la historia y las ciencias sociales (contradiciendo palmariamente a los fundadores del marxismo): "La investigación histórica cumple una función instrumental... para la comprobación (y desarrollo posterior) de teorías científico sociales [...] la historia, como tal, no es susceptible de teorización", La reconstrucción del materialismo histórico, Madrid, 1986, pp. 183-185.

${ }^{65}$ Se sugiere, en resumidas cuentas, que si un joven quiere "progresar" académicamente ha de frenar su ambición en cuanto a innovación y pensamiento, debiendo reducirse al trabajo empírico y los enfoques de sus mayores, confundiendo por tanto formación 
con la oposición larvada a pensar la historia. Se trata de un cliché activo en nuestro medio, manifiestamente contradictorio con la apuesta oficial de las universidades por la excelencia. Sus partidarios acostumbran, si se les presenta la ocasión, a juzgar los méritos ajenos como deméritos. ${ }^{66}$ Actitudes y malas prácticas en pro de la mediocridad que tienen una trascendencia especialmente negativa en el oficio de la historia, donde la tradición positivista ha sido y es más intensa y duradera que en otras humanidades y ciencias sociales. ${ }^{67}$ Si hay una disciplina académica donde debiera ser obligatorio formar hoy a los jóvenes de manera teórica e interdisciplinar, animándoles a combinar fuentes con reflexión, debería ser la historia. Si tomamos en consideración nuestra deuda al respecto y también la nueva era que estamos viviendo, que es portadora de profundos cambios históricos e historiográficos, que vuelven a la historia académica a sus orígenes decimonónicos y dejan las palabras mayores sobre la historia, pasada y presente, a políticos, escritores y otros intelectuales.

Hay quien asevera, temerariamente, ${ }^{68}$ que la historia como ciencia nada tiene que ver con la física y las ciencias de la naturaleza, y todavía menos con la joven disciplina de la historia de la ciencia. Estereotipo que, como los otros mencionados, y por mencionar, nadie explica o demuestra abiertamente ${ }^{69}$ en forma académica (lo tendrían difícil); sino que se transmite bajo cuerda, eludiendo el debate, sin aportación de pruebas, por estrategia, inercia o pereza. ${ }^{70}$ Descolgarse del vigente sistema científico

con restricción; la dificultad existente para entrar en las universidades y conseguir plaza estable, facilita este presión ambiental, exagerada imaginariamente.

${ }_{66}$ Actitud por desgracia presente en los sistemas de evaluación académica, lo que convierte a menudo el pensamiento libre y la investigación innovadora en actividades épicas-éticas, sin las cuales las disciplinas se anquilosan.

${ }^{67}$ Incluso en las facultades de Filología o Derecho se dedica más atención a la teoría que en las facultades donde se imparte el grado de Historia (al menos en España), donde existen asignaturas de historiografía y metodología histórica, pero no de teoría de la historia: significativo (re) conocimiento institucional de nuestro atraso al respecto.

${ }^{68}$ Atrevimiento facilitado por el desfase entre lo mucho que acostumbra a saber el historiador de su tema "concreto" y lo poco que conoce sobre el pensamiento historiográfico y teórico producido por nuestra disciplina u otras ciencias.

${ }^{69}$ Como no hay regla sin excepción, hay que citar un breve y desconocido trabajo de Juan Pablo Fusi con el paradójico título de "Por una nueva historia, volver a Ranke", Perspectiva Contemporánea, Madrid, núm. 1, 1988, pp. 153-154.

${ }^{70}$ No es raro que bienintencionados transmisores del gran retorno reconozcan (privadamente) su falta de formación y saber historiográfico, lo que no justifica los resultados dañinos que estamos elucidando. 
en su conjunto, al tiempo que se congela en su estadio positivista la ciencia histórica, es, en el fondo y en la forma, una maniobra defensiva para excusar la falta de actualización, en este caso del concepto de la historia como ciencia. ${ }^{71}$ No nos cansaremos de recordar que la ciencia en general ${ }^{72}$ ha dejado de ser positivista desde principios del siglo $\mathrm{xx}$ con el principio de incertidumbre de Heisenberg, la teoría de la relatividad de Einstein y la teoría cuántica de Planck. Proceso que se completó en los años 60 y 70 al entrar la historia de la ciencia en su actual fase pospositivista con Thomas S. Kuhn. ${ }^{73}$ La puesta al día de noción científica de la historia (reintroduciendo el papel del sujeto duplo) es, en nuestra opinión, la clave de bóveda de una necesaria adaptación del historiador al siglo xxi que no conlleve la marginación de la escritura profesional de la historia como erudición reciclada al servicio, por activa o por pasiva, de los poderes de nuestro tiempo.

Parte obligada de esta regresión historiográfica que estamos evaluando, donde las partes se complementan entre sí como las piezas de un rompecabezas, es el ya mencionado "olvido" de las críticas hechas al positivismo por parte del materialismo histórico, Annales y el neopositivismo que iluminó y propulsó a los historiadores del siglo xx que conquistó para la historia un lugar relevante, dentro y fuera de la academia, que hoy se está perdiendo, pese al creciente interés público por nuestro objeto de estudio.

Felizmente bastantes colegas continúan trabajando las líneas temáticas de las nuevas historias del siglo pasado a modo de especialidades "concretas", empezando por la historia económica-social. Pero también es cierto

${ }^{71}$ Hibernación epistemológica de la historia como actividad académica que ha amparado en la academia de habla inglesa, y sus zonas de influencia, la interesada bipolarización, animada desde ambos extremos, entre positivistas (pragmáticos) y posmodernos (teóricos), ignorando supinamente la revolución historiográfica del siglo xx.

${ }^{72}$ El origen y la evolución de la ciencia están, y seguirán estando en el futuro, marcados por las innovaciones y teorizaciones de las ciencias de la naturaleza, desde el siglo XviI hasta la física de partículas y cosmológica, las ciencias de la computación y la biología molecular; venimos insistiendo sobre este dato desde la prehistoria de $\mathrm{HaD}$ como tendencia historiográfica: "La historia que viene", Historia a debate. I. Pasado y futuro, Santiago, 1995, pp. 95-117 en: www.h-debate.com/cbarros/spanish/historia_que\%20viene.htm.

${ }^{73}$ Iniciamos la aplicación no mimética de la propuesta de Kuhn a la historia de la ciencia histórica con "La historia que viene" (citada anteriormente) y "El paradigma común de los historiadores del siglo xx", Medievalismo, Madrid, núm. 7, 1997, pp. 235-262 en: www.h-debate.com/cbarros/spanish/paradigma_comun.htm. 
que hace tiempo que no se defienden, ${ }^{74}$ ni tampoco se practican, ${ }^{75}$ las contribuciones más avanzadas ${ }^{76}$ del marxismo y Annales como la "historia total", la historia teórica o el compromiso del historiador con la sociedad (pasado-presente-futuro). La prueba es que somos relativamente pocos quienes cuestionamos en público el retorno triunfal de Ranke, Seignobos y Langlois. ${ }^{77}$ Primera consecuencia de la desaparición en las dos últimas décadas de las vanguardias historiográficas del siglo xx como corrientes colectivas, lo que dejó su continuidad al albur de iniciativas individuales en el ámbito de las investigaciones "concretas", sin reivindicaciones, debates y reflexiones de carácter general, en un contexto de grandes deterioros, retornos y fragmentaciones.

Hacer "historia de la historia", es decir, hacer historiografía, ${ }^{78}$ para el viejo positivismo nunca fue más allá de describir autores y obras con un criterio temporal y temático, ${ }^{79} \sin$ otras "complicaciones". Un síntoma más por tanto del regreso al positivismo es, en consecuencia, el revival -o la continuidad- de una historiografía descriptiva de autores y obras, con énfasis en lo mejor de los casos en lo académico-institucional.

${ }^{74}$ La gran excepción fue E. J. Hobsbawm que siguió, hasta los 95 años, luchando por un marxismo historiográfico sin concesiones academicistas, pese a la ausencia de Past and Present como tendencia historiográfica organizada en Gran Bretaña, cuyo espacio hoy ocupan en gran medida positivistas y posmodernos.

${ }^{75}$ Quienes lo hacemos estamos en Historia a Debate y otras iniciativas de reconstrucción paradigmática de forma más parcial.

${ }^{76}$ Los aportes más vanguardistas son, como es natural, los más cuestionados o silenciados por la academia más positivista, tradicional o retornada.

77 La no defensa pública en Francia de los paradigmas de Annales frente a los mandarines de los retornos, es si cabe más dolorosa y guarda evidente relación con la progresiva pérdida de influencia internacional de la lengua, la cultura y la academia francesas en este mundo globalizado.

78 "Historiografía" es el término más usado académicamente para referirse a la historia de la historia y de los historiadores, sus corrientes y paradigmas, si bien se continúa utilizando en países de influencia anglosajona la terminología tradicional de Benedetto Croce de "historia de la historiografía" (Teoría e historia de la historiografía, 1917); equívoca en nuestra opinión, ya que según la formulación de Croce "historiografía" sería lo que investigamos y escribimos los historiadores de oficio, es decir, "historia"; así y todo, igual nos entendemos.

79 En el siglo xx se pasó de la historiografía de autores a la historiografía de tendencias, y más recientemente a la historiografía de paradigmas; ver "Formas de hacer historiografía", conferencia en el i Simposio Internacional Ensino da História e História da Educaçâo de la Universidade Federal dos Vales do Jequitinhonha e Mucuri, Diamantina, 5 de diciembre de 2012 en: http://youtu.be/68VdRwvBjGo. 
Ante la experiencia vivida del carácter colectivo de la renovación de la historia en el siglo $\mathrm{xx}$, algunos se sienten obligados a hablar de tendencias, ${ }^{80}$ aunque si tienen que escribir sobre la historiografía inmediata, reciente, no identifican las tendencias realmente actuales sino que regresan el análisis positivista autor-obra como puerto seguro. Denominando extrañamente "tendencias" a simples líneas de investigación, temáticas y otras especializaciones "concretas", ${ }^{81}$ con enfoques más o menos nuevos (con frecuencia del último tercio del pasado siglo) nada homologables, independientemente de su interés y proyección, a las tendencias historiográficas que hasta ahora han sido, tendencias transversales que tuvieron en común la participación de historiadores de distintas especialidades temáticas y cronológicas que compartieron paradigmas generales referidos al oficio de historiador, disponiendo de claros liderazgos y medios académicos de expresión, sin dejar de promover (en un segundo plano) líneas "concretas" de investigación ${ }^{82}$ que todavía sobreviven al margen de las escuelas que las promovieron en el siglo pasado.

En 2001 hemos determinado en el preámbulo del "Manifiesto historiográfico", como resultado de nuestro debate, reflexión e investigación, cuatro grandes tendencias de la historiografía internacional: el retorno al positivismo, continuidad de la historiografía de los años 60 y 70, historia posmoderna y nuevo paradigma historiográfico. ${ }^{83}$ Para España, y conectado en parte con lo anterior, he definido asimismo tres grandes tendencias actuales, por orden de aparición: Historia a Debate, Idea Histórica de España, Recuperación de la Memoria Histórica ${ }^{84}$ Posibles razones de que estas corrientes historiográficas auténticamente presentes no

\footnotetext{
${ }^{80}$ Enmascarando que las tendencias del siglo xx son, desde hace 20 años, tradiciones más que movimientos académicamente activos.

${ }^{81}$ No hay más que ver los manuales comerciales que las editoriales encargan en España para la materia universitaria obligatoria "Tendencias historiográficas actuales".

${ }^{82}$ Líneas temáticas derivadas de reflexiones y planteamientos de fondo metodológico, historiográfico o teórico marxistas o annalistes, que sirvieron de referentes para historiadores que no querían hacer "lo de siempre", en un tiempo histórico e historiográfico en que el cambio y la innovación estaban de moda.

${ }^{83}$ Manifiesto historiográfico de HaD, 11/9/2001 en: www.h-debate.com/Spanish/ manifiesto/manifiesto_had.htm; Carlos Barros, "Panorama actual de la historiografía internacional” Barranquilla, 2009, en: http://www.goear.com/listen/5fba228/panoramaactual-de-la-historiografia-internacional-barranquilla-26509-carlos-barros-.

${ }^{84}$ Carlos Barros, "Últimas tendencias de la historiografía española", Montevideo, 2007 en: www.h-debate.com/Spanish/presentaciones/lugares/montevideo3/audio.htm
} 
aparezcan en la mayoría de los manuales que estamos criticando por: 1) la falta de perspectiva o interés de los autores (por cuestión generacional $\mathrm{u}$ otro motivo personal) con las tendencias actuales y su futuro; 2) porque implicaría hacer pública la declaración de la propia posición y compromiso historiográficos; 3 ) porque exigiría, en todo caso, una investigación de la historiografía reciente que fuese más allá del autor-obra positivista, buscando movimientos colectivos en base a las fuentes de la historiografía digital.

Manuales de historiografía escasamente actualizada que vienen a reforzar, por omisión, la precoz implantación de la teoría del conocimiento histórico del positivismo decimonónico en parte de los alumnos, a contrapelo de la pública pujanza social y global de las tendencias verdaderamente actuales. Movimientos coetáneos de historiadores que buscan de manera plural (con frecuencia, colisionando entre sí) nuevas relaciones pasado-presente-futuro, sin rehuir en general el debate, desarrollando una dimensión reflexiva (unas más que otras) conectada en mayor o menor medida con la sociedad, la cultura y la política de nuestro tiempo. ${ }^{85}$

La táctica de avestruz sobre las tendencias actuales en estos manuales de encargo ${ }^{86}$ que viene a confirmar lo "no-dicho" como la vía fundamental que ha permitido al positivismo regresar silenciosamente en el presente siglo. Siendo tarea prioritaria del historiógrafo avisado desvelar precisamente aquello que no se manifiesta en la superficie de las cosas, conforme al método de Marx. ${ }^{87}$ compatriota y contemporáneo de Ranke, del cual divergía no sólo ideológicamente sino también en el concepto de ciencia y su aplicación a la historia. Lo que parecen ignorar aquellos historiadores que

${ }^{85}$ El caso más claro es la Idea Histórica de España: corriente alentada por el primer Gobierno de José María Aznar, tiene continuidad político-institucional hoy a través de la Real Academia de la Historia y se acaba de manifestar públicamente (diciembre de 2013) en oposición a los historiadores catalanistas en el contexto de un encendido debate sobre las relaciones actuales e históricas entre España y Cataluña.

${ }^{86}$ La consciente ignorancia sobre las tendencias actuales es síntoma, causa y consecuencias de una historiografía actual individualista y fragmentaria: punto de encuentro del positivismo y el posmodernismo en el tránsito del siglo xx al siglo xxI; Carlos Barros, "Historia a Debate, un paradigma global para la escritura de la historia", Santiago de Compostela, 2004 en: http://youtu.be/yis9kvB8lt8.

87 "Toda ciencia sería superflua si la forma de manifestación y la esencia de las cosas coincidiesen directamente", Carlos Marx, El Capital, libro 8, México, Siglo XXI, 1981, p. 1041; el marxismo aflora en el siglo Xxi, en no pocos aspectos, por causa de la vuelta del viejo adversario positivista con sus correlatos actuales neoliberales y neoconservadores. 
se consideraron cercanos al marxismo y se guían pragmáticamente ahora por la hiper-empirista noción rankeana de la historia como ciencia. ${ }^{88}$

Para terminar, trataremos otro indicio del retroceso al positivismo: la ruptura entre la historia que se escribe y la historia que se vive, entre la academia y la sociedad, en momentos de grandes cambios y convulsiones históricas. Desfase acumulativo que ilustra la regresión científica y social que conlleva el repliegue positivista de sectores de la historia académica de la caída del muro de Berlín en adelante. ${ }^{89}$ Refugiarse en las viejas certidumbres historiográficas, epistemológicas y temáticas, puede ser compresible en lo personal, ${ }^{90}$ pero resulta tóxico para el presente y el futuro de la disciplina de la Historia, víctima perfecta de la mercantilización galopante, en mayor medida incluso que el resto de la universidad.

En resumen, la causa de la aceleración histórica posterior a 1989 consiste en distinguir entre el historiador y el ciudadano, y más todavía después de la crisis del 2008 en vigor, tanto individual como colectivamente. Nunca fue tan cierto eso de que la historia si quiere tener futuro ha de preocuparse del futuro, ${ }^{91}$ mostrando su utilidad en un momento crítico para el futuro de la humanidad y de las humanidades.

Muchos creemos que es un mal negocio, seguir repitiendo como avestruces que somos una cosa como historiadores y otra distinta como ciudadanos, como si eso fuese hoy posible o creíble, más allá de las indudables diferencias entre ambos tipos de actividad. Pretender ser una cosa en la

\footnotetext{
${ }^{88}$ Ha contribuido a esta confusión la asunción implícita (en el marco del fructífero paradigma común de los historiadores del siglo xx) por parte de la historiografía marxista y de Annales de aportes neopositivistas de vanguardia, como el método hipotéticodeductivo (v. g. Ciro. F. Cardoso, Introducción al trabajo de la investigación histórica. Conocimiento, método, historia, Barcelona, 1982, pp. 19-53) o la historia cuantitativa, reapropiada y bautizada en los años 70 como histoire sérielle por los terceros Annales.

${ }^{89}$ El fracaso del tournant critique de Annales (1989-1990), junto con la crisis del marxismo y el apogeo de la segmentación de la historia en los reaccionarios años 90, marcan la bifurcación cada vez más clara entre partidarios de un nuevo paradigma-consenso, que hacen nuestra la revolución historiográfica del siglo xx con sus luces y sus sombras, y los retornados a la historiografía anterior a la escuela francesa y el marxismo historiográfico.

90 Para la generación de los años 60 y 70 estas salidas individuales son efecto del agotamiento de las tendencias de aquellos años; añadamos, en el caso de algunos jóvenes, la ilusión de que renunciando a la innovación y el compromiso favorecen la posibilidad de una carrera académica, gravemente erosionada en la realidad por los recortes y las políticas económicas neoliberales.

${ }^{91}$ Punto núm. 12 de "La historia que viene", Historia a debate. I. Pasado y futuro, Santiago, 1995, pp. 95-117 en: www.h-debate.com/cbarros/spanish/historia_que\%20viene.htm.
} 
academia y otra a menudo opuesta en la sociedad ${ }^{92}$ sólo se puede conciliar asumiendo el paradigma positivista (con todo los aderezos que se quieran), cuyo idealismo objetivista e academicista legitima la escisión entre una historia mediata (pasada) e inmediata, entre el objeto y el sujeto (doble) de la historia, lo cual es aprovechado cada vez más por actores actuales para enmendar e impugnar (vía novela histórica o memoria histórica, por ejemplo) la historia académica.

Algunos de los argumentos que venimos utilizando para reprobar el repliegue positivista de la historiografía desde los años 90, ya han sido utilizados académicamente en el siglo xx, por Annales y el marxismo, para hacer avanzar la historia. ¿Qué hay de nuevo medio siglo después? 1) El contexto de una historia profesional menos elitista que está presente en todas las universidades públicas del mundo y sigue atrayendo a muchos miles de estudiantes, por no hablar de su peso en la enseñanza media. 2) No es posible borrar desde el poder académico, político o económico ${ }^{93}$ la revolución historiográfica del siglo xx que demostró, con sus errores y aciertos, que fuera del positivismo que "otra historia es posible". 3) La irrupción de una crisis económica, social y política que sitúa a los estudios e investigaciones universitarias, a la enseñanza y la ciencia en general, en el centro de la tormenta, transmutando en palabras peligrosamente huecas el pretendido divorcio entre la historia que se escribe académicamente y la historia que se hace social y políticamente, de la cual dependemos en última instancia.

¿POR QUÉ RENACE EL VIEJO POSITIVISMO?

¿Cuáles son las causas internas y externas de este inesperado impulso del viejo positivismo en pleno siglo xxi? Ya hicimos referencia a la ola con-

\footnotetext{
92 Por ejemplo, valorar positivamente los nuevos movimientos sociales, e incluso participar en ellos, al tiempo que se entroniza académicamente una epistemología negadora del sujeto colectivo de la historia, sea social sea historiográfico: esquizofrenia bastante común en nuestro medio.

93 Salvo que se hiciese desparecer (imponiendo una historia oficial conservadora) la libertad académica, el debate y la reflexión entre los historiadores, para evitarlo (y construir una alternativa de futuro) creamos $\mathrm{HaD}$ como red de historiadores comprometidos hace dos décadas, cuando este fenómeno de retroceso a los orígenes positivistas estaba en sus inicios y la democracia menos devaluada en Europa y otros lugares del mundo desarrollado.
} 
servadora que siguió a la caída del Muro de Berlín ${ }^{94}$ y que tanto afectó a las ciencias humanas en Europa y América. Lo más obvio, así y todo, es la causalidad interna: el declive sin aparente retorno ${ }^{95}$ de las tendencias críticas comprometidas con la sociedad y la innovación académica difundidas en los años 60 y 70. Decadencia que viví de primera mano, antes y durante los inicios de Historia a Debate, junto a la escuela renovadora francesa ${ }^{96}$ y Past and Present que eran espacios fecundos de militancia historiográfica ocupados dialécticamente, por una historia tradicional que volvió por sus fueros, temas y conceptos, sin mayores exigencias de innovación y compromiso para sus retornados y a menudo embozados seguidores. Al dejar de funcionar las vanguardias historiográficas como movimientos académicos activos, críticos y colectivos, la primera consecuencia fue el resurgir paulatino (primero sus temas, después su teoría del conocimiento) de la vieja histoire historizante, événementielle, epidérmica y descriptiva, interesada ante todo por la biografía de "grandes hombres" y una historia política, institucional, narrativa, diplomática, militar de metodología naturalmente positivista. ${ }^{97}$

Involutivo contexto disciplinar, sobredeterminado por el conservadurismo ambiental y el peso de la biología en los académicos, que desencadena

${ }_{94}$ Los hechos 1989-1991 no sólo significaron el fin del marxismo soviético, marcaron también la crisis finisecular del marxismo en su conjunto (que venía de atrás) y de otras ideologías de progreso como la socialdemocracia y el liberalismo de raíz progresista, que fue reemplazado en los años 90 por un neoliberalismo que dio nueva vida al conservadurismo tradicional; corrimiento político, ideológico y mental hacia la derecha que dejó campo abierto al posmodernismo como teoría del pesimismo, el desencanto y el descompromiso. ${ }^{95}$ En el "Manifiesto historiográfico" de HaD (2001) recuperamos, de todos modos, autocríticamente las contribuciones más vanguardistas, cumplidas en diferente grado, de la revolución historiográfica del siglo xx como el espíritu innovador, la historia total, la historia teórica, la interdisciplinariedad, la formación de tendencias o el compromiso del historiador.

${ }_{96}$ Analicé hace dos décadas las críticas por la derecha (H. Coutau-Begarie) y por la izquierda (F. Dosse) que recibía Annales en su crepúsculo, ver "La 'Nouvelle Histoire' y sus críticos”, Manuscrits. Revista d'Història Moderna, núm. 9, Barcelona, 1991, pp. 83-111 en: www.h-debate.com/cbarros/spanish/nouvelle.htm; ambos críticos tenían su parte de razón, la historia tradicional retornó en Francia y la tradición annaliste no francesa volvió en la "periferia" latina a los orígenes de Annales como demuestra la emergencia de Historia a Debate como red y tendencia, a partir del fracaso del tournant critique de Annales (19891990) del que participé.

${ }_{97}$ Paralelamente, el posmodernismo anglosajón aprovechó para ocupar el notable espacio de debate, teoría y reflexión que habían creado en Gran Bretaña el marxismo de Past and Present, y en los EE UU, la Radical History. 
una reacción instintiva y adaptativa en no pocos colegas negativa para el presente y futuro de la historia como profesión y ciencia social. Dicen los psicólogos que la reacción humana habitual ante una situación de cambio o estrés es "huir o luchar": el agotamiento del impulso renovador de la historiografía ha beneficiado claramente la "huida" silenciosa de colegas valiosos al pasado historiográfico. ${ }^{98}$

El ascenso durante los años 90 de los valores y de las ideologías hostiles a la historia tal y como se entendió en el siglo xx, tanto en lo académico como en lo político, provocó una frustración historiográfica en curso que conlleva el olvido de cómo y por qué nacieron las pretéritas nuevas historias. Sin comprender que si en el siglo xx fueron los movimientos sociales tradicionales quienes acompañaron y alentaron la renovación historiográfica, ahora el futuro de la historia cabalga, o debe cabalgar, sobre una ola mundial que emerge con fuerza desde el inicio en Seattle del movimiento antiglobalización en 1999, ${ }^{99}$ reemplazado en 2011 por el movimiento global de los indignados, que tuvo sus comienzos en 2011 en el Magreb y España y se extendió después a EE. UU., México y Brasil. Fases de una inacabada lucha internacional por una globalización alternativa, más humana, y por lo tanto más amiga de las humanidades, de la cultura, la educación y una universidad que no estén al servicio del comercio, los beneficios empresariales y la especulación financiera.

Al igual que en en las décadas del 60 y el 70 soy optimista ${ }^{100}$ sobre el futuro de la historia. En los dos sentidos habituales del concepto: la historia que vivimos y la historia que escribimos, sobre la que podemos actuar más positiva y directamente, siempre y cuando seamos capaces de revertir la inercia de esa parte de la academia historiográfica que predica el aislacionismo para nuestra profesión, correlato del retorno positivista que ponemos a debate. Aislacionismo que viene en el peor momento si consideramos lo que está pasando en el mundo: una crisis económica, social y universitaria que dejará hondas secuelas, especialmente en la Eu-

\footnotetext{
98 Desencanto y marcha atrás que es anterior, hay que decirlo, a la jubilación laboral de la generación rompedora de los años 60 y 70, proceso que está teniendo lugar en esta segunda década del siglo xxi: veinte años después del giro conservador de la historiografía internacional que venimos desplazando.

${ }^{99}$ Precedido por el levantamiento de Chiapas en 1994, Carlos Barros, "Chiapas y la escritura de la historia”, revista Este/Sur, n² 254, San Cristóbal de las Casas, noviembre de 1999 en: http://www.h-debate.com/cbarros/spanish/chiapas-castellano.htm.

100 Ser optimista y ver las posibilidades es lo propio del que quiere y actúa para cambiar la historia, otra cosa es el resultado complejo de la relación de fuerzas.
} 
ropa latina. Separar hoy la historia que se hace de la historia que se escribe contribuye, por otro lado, al agravamiento de las condiciones pre-existentes para el relevo generacional, por la gran cantidad de plazas para profesores e investigadores jóvenes que se están anulando por las políticas de austeridad que imponen los poderes financieros. Urge pues defender la universidad pública, no sólo como ciudadanos también como historiadores y educadores, explicando a los jóvenes que tienen vocación para la investigación que sus posibilidades de futuro dependen del desenlace final de las luchas sociales y políticas de este momento histórico.

En la academia tenemos también muchos jóvenes inteligentes y sensibles que no dan la espalda a la historia que sufren y son conocedores que para ser buen historiador, aquí y ahora, hay que hacer una historia distinta de la tradicional y coadyuvar a las luchas académicas y no académicas por invertir estas políticas neoliberales que mercantilizan la universidad, impiden la creación de plazas de docencia e investigación y recortan el espacio de las ciencias humanas. ${ }^{101}$ Son precisamente los que teniendo vocación académica acostumbran a estar más lúcidos y motivados para llegar al final del túnel. Otros, menos sagaces y comprometidos con la historia y sus problemas, frecuentemente con buenas calificaciones pero menos preparados para la vida real, no suelen salir del túnel: se cansan pronto y abandonan la carrera cuando se les acaba la beca. Lo vemos constantemente.

Otra forma de aislacionismo, resultado perverso del retorno de los positivistas, es la desconexión de esa parte de la escritura de la historia de las fuerzas innovadoras del momento actual: académicas, sociales y digitales. Me refiero a las disciplinas científicas más avanzadas (física, biología, informática y ciencias de la comunicación), por un lado, los nuevos movimientos sociales, por el otro, y como nexo global: las nuevas tecnologías de la información.

No digo nada nuevo, pasó lo mismo en el siglo xix: ¿no nace el positivismo historiográfico al calor del nacionalismo emergente? Los referentes de la historia positivista, Leopold von Ranke el primero, eran parte del movimiento político-social dominante, y luchaban con sus obras por el éxito y consolidación del Estado-Nación (o de las naciones sin Estado en otros lugares), aunque ellos decían ser "neutrales" a la hora de hacer

${ }^{101}$ Hace tiempo que pasa esto en las universidades privadas, salvo excepciones. 
historia, ${ }^{102}$ viviendo así en constante contradicción, favorecidos y financiados en cualquier caso por el Estado en construcción (o simplemente añorado) que exigía una historia propia, más rigurosa y documentada. Un siglo después, la historia no se concibe ya sin el uso de documentos, los viejos Estados-Nación se resisten a la globalización y los nuevos sujetos históricos precisan de los historiadores bastante más que pericia con las fuentes.

Acaso en el siglo xx, ¿el marxismo y Annales se hubieran desarrollado como corrientes historiográficas hegemónicas en Europa (por ejemplo Alemania) y América (salvo EE. UU.), sin el movimiento obrero, estudiantil y demás movimientos sociales del "siglo de las masas"? Y después del marxismo y Annales, ¿es qué los movimientos feminista, ecologista o pacifista, no han generado asimismo nuevos enfoques de investigación? Igual se puede decir en el cambio de siglo de la globalización y la antiglobalización con la World History ${ }^{103}$ y la Historia Inmediata. ${ }^{104}$ No obstante, lo específico del momento actual, texto y contexto, no es tanto la temática que se investiga, o se pueda investigar, como la noción epistemológica de la historia, cuya cientificidad se niega (posmodernos) o se reafirma torpemente (retornados) en los márgenes del debate. ${ }^{105}$

Entre 2011 y 2013 hemos vivido, tanto en Europa como en América, una movilización mundial de indignación social de origen africano que no tiene parangón desde mayo del $68 .{ }^{106}$ Iniciado en Túnez, este nuevo

${ }^{102}$ Para diferenciarse justamente de una historia de escritores, aficionados y políticos carentes de un mínimo conocimiento de las fuentes cuando no inventores o manipuladores de los hechos históricos.

${ }^{103}$ Carlos Barros, "Primeras conclusiones del in Congreso Internacional Historia a Debate (14-18 de Julio de 2004)", Historia a debate. I. Reconstrucción, Santiago, Historia a Debate, 2009, pp. 67-84 en: www.h-debate.com/cbarros/spanish/articulos/nuevo_paradigma/ conclusiones.../primeras\%20conclusiones.htm.

${ }^{104}$ Es por ello que la pionera Histoire du Temp Présent fundada en 1978 por François Bédarida (imitada en España y otros países) para la investigación de la II Guerra Mundial (y posteriormente de la guerra de Argelia) no es lo mismo que la Historia realmente Inmediata que iniciamos en Historia a Debate el año 2000 en plena mundialización, Carlos Barros, "La Historia Inmediata, un nuevo territorio del historiador" (2008) en: www.hdebate.com/Spanish/presentaciones/lugares/venezuela/av.htm.

${ }^{105}$ El desinterés de jóvenes y menos jóvenes por este crucial debate es otra de las consecuencias del repliegue: reduce la producción bibliográfica en una cuestión cuantitativa e curricular.

${ }^{106}$ Carlos Barros, "Historia Inmediata: de Chiapas a los indignados", conferencia inaugural del XXvir Congreso Internacional Historia Regional / VII Encuentro de Historiadores de Sinaloa. Culiacán, 8 de diciembre de 2011 en: http://www.youtube.com/ watch?v=bHqkczWoBwE. 
movimiento social de dimensión global saltó a España el 15 de mayo de $2011(15 \mathrm{M}),{ }^{107}$ donde se acuñó y difundió el término "indignados", tomando el término del libro de Hessel; ${ }^{108}$ esto sucedió en septiembre en Estados Unidos (Occupy Wall Street), en 2012 en México (\# Yosoy132) y en 2013 en Brasil. En todos los casos, los estudiantes, como en el 68, y de manera más destacada los graduados universitarios, ${ }^{109}$ constituyen la parte más activa de este nuevo ciclo histórico de movilizaciones sociales juveniles críticas con el capitalismo global. Movimiento de los indignados que releva al medio fenecido movimiento altermundista, ${ }^{110}$ mostrando una vez más que la sociedad civil global se reinventa: ha venido para quedarse.

\section{VEINTE AÑOS DE NUEVO PARADIGMA}

La historia que vivimos se mueve rápidamente, por arriba y por abajo, hacia atrás y hacia adelante: los historiadores conscientes del carácter objetivamente colectivo de nuestro oficio tenemos que optar, el futuro de nuestra disciplina depende de ello. Desde $\mathrm{HaD}$ decimos hace dos décadas que ni el positivismo ni el posmodernismo, son diferentes y contradictorias formas de desandar el camino y asumir la derrota. Debemos construir nuevos paradigmas que nos aseguren un lugar en el siglo xxi y que no desmerezca al ocupado por la historia profesional en el siglo xx. Historia a Debate es la prueba de que es viable una escritura de la historia que mire hacia adelante, sin hacer tabla rasa del siglo xx; potencialmente mayoritaria, cuando menos, en el ámbito académico latino. Veinte años de experiencia, propuestas, debates e investigaciones, muestran la necesidad y la viabilidad del nuevo paradigma (consenso según Kuhn) que venimos

107 Primero tuvo lugar el movimiento indignado islandés de 2008, al comienzo de la crisis, pero fue el estallido de la crisis en España en 2010 y el ejemplo del Magreb, a comienzos de 2011, lo que disparó el 15M español: el movimiento indignado con mayor capacidad de convocatoria internacional en estos tres años de la segunda década del siglo Xxi.

108 Stéphane Hessel, Indignez-vous !, París, 2010 (ed. esp., marzo de 2011).

109 La Universidad sufre como nadie el masivo desempleo juvenil en los países más afectados por la crisis y las políticas de austeridad impuestas por los mercados financieros: el 44,85\% de los 50000 miembros del 15M que responden a una encuesta en 2013 son licenciados universitarios en: http://www.ahoratudecides.es/index.php/resultados/.

${ }_{110}$ Los altermundistas mantienen algunos Foros pero ya no sus típicas convocatorias de movilización social, puntales y concentradas, ante las instituciones económicas globales, reemplazadas a partir de 2011 por grandes movilizaciones nacionales con una base común que saltan de país en país, junto con jornadas internacionales organizadas tanto por el $15 \mathrm{M}$ como por Occupy Wall Street. 
practicando, sin "pensamientos únicos", combinando incesantemente el debate con sucesivos consensos, aprendiendo de nuestros interlocutores, dentro o fuera de nuestra red-movimiento, a perfilar dinámicamente nuestras posiciones metodológicas e historiográficas, epistemológicas y sociales.

Remataremos nuestra exposición haciendo referencia a la dilatada y diversa trayectoria de Historia a Debate ${ }^{111}$ desde la nueva historia al nuevo paradigma, en contextos históricos tan dispares como la caída del Muro de Berlín, el atentado de la Torres Gemelas, la crisis económica mundial o la emergencia del movimiento social global. El objetivo de este resumen final es que se comprenda mejor el carácter constructivo y proactivo de nuestra crítica al retorno del positivismo, y de paso a su complementario posmodernista, filosóficamente residual en este siglo de búsquedas de una nueva Ilustración global.

En 1993, cuatro años después de la caída del Muro de Berlín, organizamos en Santiago de Compostela el I Congreso Internacional de Historia a Debate, con la colaboración de Annales y Past and Present. Terminadas las jornadas de trabajo tome conciencia, en mi condición de promotor y máximo responsable, del agotamiento de los focos de renovación historiográfica, en francés y en inglés, que habían iluminado la profesión de historiador en el pequeño siglo xx. La revista Annales seguía editándose, ciertamente, pero había dejado de representar una escuela o movimiento colectivo, y lo mismo podríamos decir de la revista de historia que, buscando conectar pasado y presente, fue creada en 1952 por el grupo de historiadores del Partido Comunista Británico. Las tendencias historiográficas que eran percibidas en los años 90, y más aún en los años 2000 como tradiciones más que como realidades historiográficas activas. ${ }^{112}$ Nos planteamos, en consecuencia, explorar nuevas alternativas ${ }^{113}$ que recogieran el espíritu de las viejas vanguardias, respondieran a los nuevos tiempos de la historia (y la historiografía) y pudieran concitar apoyos y

111 Carlos Barros, "Historia a Debate, desde los congresos a las redes sociales", Diamantina, 2012 en: http://www.youtube.com/watch?v=kl6TsMmCwaU.

112 Annales y Past and Present volvieron a ser simples revistas, sin dinámicas colectivas de debates y consensos, en sus países de origen, no así en determinadas periferias donde siguieron percibiéndose como "tendencias historiográficas actuales" pese a las décadas transcurridas.

${ }^{113}$ Hicimos una primera aproximación en "La historia que viene", Historia a debate. I. Pasado y futuro, Santiago, 1995, pp. 95-117 en: www.h-debate.com/cbarros/spanish/historia_ que\%20viene.htm. 
complicidades en diversas historiografías y continentes: así nació Historia a Debate. ${ }^{114}$

Aprendimos rápidamente cómo evoluciona la ciencia con Thomas S. Kuhn y su libro La estructura de las revoluciones científicas (1962) y otros escritos. Aplicando de forma rectificada a la historia de la historia los conceptos de paradigma como consenso, comunidad de especialistas y cambio de paradigma (revolución científica). Kuhn decía que las ciencias no avanzan por acumulación sino mediante revoluciones científicas. Es verdad, las disciplinas avanzan mediante rupturas, pero también añadimos por acumulación, según nuestra propia experiencia como historiadores de la escritura de esta materia. Cada nuevo paradigma recoge y mantiene el consenso anterior, en un nuevo contexto histórico e historiográfico. Es así como del positivismo, la primera lectura científica de nuestra disciplina, Annales y el marxismo aprendieron el rigor documental a través del uso crítico de las fuentes, superponiendo al oficio de historiar otros paradigmas temáticos e historiográficos, junto con compromisos sociales y políticos bien distintos al positivismo. El error estuvo, con todo, en no haber desarrollado más en el siglo xx de forma clara y consecuente una epistemología distinta ${ }^{115}$ al objetivismo sacro de Ranke, Langlois y Seignobos. Una teoría del conocimiento histórico que restituyese con nitidez el papel activo del historiador como sujeto cognoscente, más allá del falsacionismo de Popper (pensado para atacar al marxismo), donde la verificación empirista siempre tenía la última y verdadera palabra. ${ }^{116}$ En resumen, a pesar de la "revolución historiográfica del siglo xx", el positivismo epistemológico nunca se fue del todo, de ahí la facilidad con que sectores de los annalistes y marxistas desencantados (y âgées) retornan a la "idolatría de las fuentes".

114 Carlos Barros, "Historia a Debate, tendencia historiográfica latina y global", Aula Historia Social, Valencia, núm. 13, primavera 2004, pp. 84-90 en: www.h-debate.com/ cbarros/spanish/articulos/nuevo_paradigma/tendencia.htm.

115 E. H. Carr lo intentó en ¿Qué es la historia? (Londres, 1961; Barcelona, 1983) pero no tuvo éxito, el marxismo historiográfico siguió guiándose en su mayoría, al igual que Annales, por una noción de la historia como "ciencia de la sociedad (o los hombres) en el tiempo", que dejaba fuera de la definición al propio historiador, Carlos Barros, "Por un nuevo concepto de la historia como ciencia" (2005) en: http://www.h-debate.com/Spanish/ presentaciones/lugares/quito.htm.

${ }^{116}$ A partir de Kuhn sabemos que la(s) verdad(es) histórica(s) la decide en último término la comunidad de especialistas. 
De las nuevas historias de los años 60 y 70, asumimos y reformulamos (reconociendo defectos y limitaciones) sus propuestas más avanzadas, incluso más imprescindibles en el siglo xxi que en el siglo xx, entre las que acostumbramos a destacar tres, historia total, compromiso y teoría: 1) Hoy es más obligatorio que nunca una historia más global, vista la fragmentación creciente de nuestra disciplina, a contrapelo del mundo en que vivimos; 2) lo que hace ineludible una historia más comprometida con el presente y el futuro, porque siendo el futuro más ignoto que nunca, puede pasarnos lo peor, debemos contribuir desde la historia a que las mejores hipótesis se confirmen, aportando el punto de vista del historiador de profesión; 3) la herencia recibida, junto con la complejidad presente, exigen una historia más pensada, difícilmente se puede hacer ahora una buena historia sin reflexionar sobre el método, la historiografía y la teoría. ${ }^{117}$

Contra otras previsiones interesadas, desde la caída del Muro la historia ha cambiado enormemente: urge mudar también la historiografía si no queremos que nuestra disciplina se convierta en una estatua de sal como la mujer de Lot. Para evitarlo elaboramos un nuevo concepto de la historia profesional que denominamos "ciencia con sujeto". ${ }^{118}$ Ciencia histórica con un doble sujeto: social (agente histórico) y cognoscente (historiador). En el primer caso buscamos no olvidar, en tiempos de regreso "triunfal" de la historia más tradicional, el papel de la acción colectiva en la historia: una vieja y vigente contribución del marxismo historiográfico (no estructuralista). En el segundo caso reside la mayor novedad epistemológica, implica reintroducir al historiador, y a la comunidad de historiadores, como hacedor "en última instancia" de la historia que se escribe: condición subjetiva sine qua non del realismo y la cientificidad de nuestra disciplina.

Historia a Debate representa como sujeto cognoscente una nueva forma de sociabilidad académica en Internet ${ }^{119}$ centrada en un renovado interés, colectivo y generacional, por la reflexión y la autorreflexión sobre el oficio

117 Punto 13 de "La historia que viene", Historia a debate. I. Pasado y futuro, Santiago, 1995, pp. 95-117 en: www.h-debate.com/cbarros/spanish/historia_que\%20viene.htm.

118 Punto I del "Manifiesto historiográfico" de Historia a Debate; más información en Carlos Barros, "Por un nuevo concepto de la historia como ciencia" (2005) en: http:// www.h-debate.com/Spanish/presentaciones/lugares/quito.htm.

119 Carlos Barros, "La sociabilidad académica en la era global", curso de posgrado en la Universidad de Santiago de Compostela, 2007 en: http://www.youtube.com/ watch?v=uBdCgP6dPWM. 
y la escritura de la Historia. Dicho de otro modo, en un momento de grandes cambios, internos y externos, hemos incrementado nuestra capacidad de intervención historiográfica, como sujeto consciente de la historia que se escribe. Somos la avanzada de una nueva historiografía digital ${ }^{120}$ capaz de intercambiar debates y consensos en tiempo real con la participación de colegas de cientos de universidades, utilizando un medio académico de comunicación impensable para las tendencias historiográficas que nos han precedido. Gracias a esto llevamos años practicando en red una historiografía inmediata que nos permite, junto con nuestros macro congresos, organizar debates, percibir los cambios en la comunidad internacional de historiadores desde una privilegiada óptica latina, y hacer propuestas con la garantía probada de una enorme difusión nacional e internacional. Procurando y concediendo apoyos, formulando críticas, recogiendo y replanteando proposiciones y experiencias de diversos orígenes, venimos erigiendo un nuevo consenso (paradigma) para el oficio de historiador en el siglo xxi. Haciendo caso omiso, una y otra vez, de los cantos de sirena de un individualismo academicista que nos condena al "eterno retorno" a una vieja forma empirista de hacer la historia que simula vivir fuera de su tiempo.

No se puede ejercitar con éxito una historiografía de lo inmediato, sin prolongar hasta el hoy (y proyectar al mañana) nuestro objeto de investigación histórica. ${ }^{121}$ Frente a los retornados que lamentan y satanizan el "presentismo" de la nueva sociedad de la información, hemos construido sobre el terreno un concepto de Historia Inmediata ${ }^{122}$ que abarca la reflexión, el debate y la investigación participativa de los historiadores sobre hechos, procesos y movimientos sociales actuales (o recientes) de relevancia histórica, incluyendo su interacción con una historiografía asimismo actual y cambiante aunque algunos, en su aparente inmovilismo, no lo sepan o quieran ver.

120 "La nouvelle historiographie digitale". Séminaire à l'Université Catolique de Louvain (Katholieke Universiteit Leuven). Leuven, België, 8 mars 2013 en: http://youtu.be/IiugaGITug.

${ }^{121}$ Carlos Barros, “¿Es posible una Historia Inmediata?” (2002) en: www.h-debate.com/ cbarros/spanish/articulos/mentalidades/inmediata.htm; "La Historia Inmediata, un nuevo territorio del historiador" (2008) en: www.h-debate.com/Spanish/presentaciones/lugares/ venezuela/av.htm.

${ }^{122}$ Superando conceptos anteriores como Historia del Tiempo Presente o Historia del Mundo Actual implementados sobre todo en España, y otros países, para extender el campo académico o educativo de la vieja "Historia Contemporánea". 
Si los historiadores perdemos pie con la historia que vivimos, sujeta desde 1989 a notorios bandazos, retrocesos y aceleraciones, acabaremos siendo un oficio marginal, con relación a lo que fueron las nuevas historias en el siglo $\mathrm{xx}$, reducido a una pura erudición, simple entretenimiento para autores o lectores o, lo que es peor, medio de propaganda para los poderes establecidos, viejos o nuevos. 